\title{
Broiler breeders should not be reared on long photoperiods
}

\author{
P.D. Lewis ${ }^{\#}$ \& R.M. Gous \\ Animal and Poultry Science, School of Agricultural Sciences and Agribusiness, University of KwaZulu-Natal, \\ Scottsville 3209, South Africa
}

\begin{abstract}
Sexual maturity is delayed and egg numbers are reduced when broiler breeders are reared on long photoperiods. However, this is the recommended procedure for rearing spring-hatched birds in nonlightproof buildings. Research at the University of KwaZulu-Natal has suggested that this advice may be incorrect, and that precocity is not a problem in control-fed broiler breeders reared on increasing daylengths. This trial compared the responses of four broiler breeder genotypes to a typical lighting programme advocated for birds in lightproof housing with the provision of 14-h photoperiods to 20 weeks and $16 \mathrm{~h}$ in lay. The long-day rearing resulted in a 26-d delay in sexual maturation, seven fewer eggs to 60 weeks, a 2.5-g increase in egg weight, less efficient feed conversion, heavier body weights at sexual maturity and throughout the laying period, and a higher incidence of mortality. It is concluded, therefore, that broiler breeders should not be reared on long photoperiods, even when hatched in the spring and kept in nonlightproof facilities, because of the adverse consequences of a delay in the dissipation of photorefractoriness.
\end{abstract}

Keywords: Broiler breeder, light, rearing, long days, out-of-season

\# Corresponding author. E-mail: northcot.7hg@dsl.pipex.com

\section{Introduction}

Until recently, the amount of research conducted into lighting for broiler breeders has been minimal, and strategies for lighting them have generally been based on recommendations for lighting egg-laying stock. One of the long-established golden rules for lighting growing pullets has been never to increase the daylength during the rearing period. This was designed to minimise precocity and avoid the undesirable consequences of prolapses and small eggs. And so the normal advice for lighting spring-hatched pullets kept in non-lightproof facilities, including broiler breeders, has been to rear them on a constant daylength equal to the anticipated longest natural day during the rearing period; in South Africa this generally means about 14 hours. However, recent investigations at the University of KwaZulu-Natal (Gous \& Cherry, 2004; Lewis et al., 2003; 2004; 2005a; 2005b; Lewis \& Gous, 2006) have shown that broiler breeders reared on long days mature three to four weeks later than birds reared on short days, and that this results in a reduction in egg numbers and less efficient feed conversion. Whilst there is some increase in egg weight, this is normally of no economic value to a broiler breeder operation and can cause management problems in the hatchery towards the end of the laying cycle. This paper reports a comparison of the currently recommended lighting programmes for rearing in-season (8-h photoperiods during rearing) and out-of-season broiler breeders (14-h photoperiods during rearing).

\section{Materials \& Methods}

Eight hundred each of Ross 308, Ross 788, Cobb 500 and Hybro broiler breeder females were reared in lightproof litter-floor rooms on 8-h (07:00 - 15:00) or 14-h (07:00 - 21:00) photoperiods; mean illuminance produced by four $60 \mathrm{~W}$ incandescent lamps in each room was $26 \pm 2.8$ lux at a height of $30 \mathrm{~cm}$. The birds were moved to eight lightproof adult litter floor rooms at 20 weeks of age; each adult room comprised four pens, and each pen contained 100 females $\left(5.0 / \mathrm{m}^{2}\right)$ and 10 males (after $5 \%$ egg production) from one of the four genotypes ( 8 rooms x 4 genotypes x 100 birds $=3200$ female birds). On transfer at 20 weeks, the 400 pullets of each genotype that had been reared on 8-h photoperiods were abruptly changed to $12 \mathrm{~h}(07: 00-19: 00)$, followed by weekly increments of $1 \mathrm{~h}$ to reach $16 \mathrm{~h}(07: 00-23: 00)$ at 24 weeks; the 14-h birds were abruptly transferred to $16 \mathrm{~h}$ at 20 weeks. Illumination in all rooms was from a single $14 \mathrm{~W}$ compact warm-white fluorescent lamp in each pen ( $24 \pm 2.2$ lux at bird-head height). 
Table 1 Mean age at 50\% egg production, egg numbers, egg weight, egg mass, and feed conversion (including rearing feed) to 60 weeks of age for Ross 308, Ross 788, Cobb 500 and Hybro broiler breeders reared on $8 \mathrm{~h}$ and transferred to $12 \mathrm{~h}$ at 20 weeks followed by 1-h weekly increments to $16 \mathrm{~h}$, or reared on $14 \mathrm{~h}$ and transferred abruptly to $16 \mathrm{~h}$ at 20 weeks

\begin{tabular}{|c|c|c|c|c|c|}
\hline & \multicolumn{2}{|c|}{ Rearing photoperiod } & \multicolumn{3}{|c|}{ SED and Res DF } \\
\hline & $8 \mathrm{~h}$ & $14 \mathrm{~h}$ & Mean & Light & Genotype \\
\hline $\begin{array}{c}\text { Age at } 50 \% \text { lay } \\
\text { Ross } 308 \\
\text { Ross } 788 \\
\text { Cobb } 500 \\
\text { Hybro } \\
\text { Mean }\end{array}$ & $\begin{array}{l}177.8 \\
176.8 \\
179.0 \\
184.8 \\
179.6^{\mathrm{b}}\end{array}$ & $\begin{array}{l}205.3 \\
205.8 \\
204.8 \\
206.3 \\
205.5^{\text {a }}\end{array}$ & $\begin{array}{l}191.5^{\mathrm{b}} \\
191.3^{\mathrm{b}} \\
191.9^{\mathrm{b}} \\
195.5^{\mathrm{a}}\end{array}$ & $\begin{array}{c}0.78 \\
23\end{array}$ & $\begin{array}{c}1.10 \\
23\end{array}$ \\
\hline $\begin{array}{c}\text { Egg numbers ( } 1 \\
\text { Ross } 308 \\
\text { Ross } 788 \\
\text { Cobb } 500 \\
\text { Hybro } \\
\text { Mean }\end{array}$ & $\begin{array}{l}150.4 \\
154.5 \\
144.5 \\
138.2 \\
146.9^{a}\end{array}$ & $\begin{array}{l}145.9 \\
144.7 \\
133.1 \\
133.8 \\
139.4^{\mathrm{b}}\end{array}$ & $\begin{array}{l}148.2^{\mathrm{a}} \\
149.6^{\mathrm{a}} \\
138.8^{\mathrm{b}} \\
136.0^{\mathrm{b}}\end{array}$ & $\begin{array}{c}2.06 \\
15\end{array}$ & $\begin{array}{c}2.92 \\
15\end{array}$ \\
\hline $\begin{array}{c}\text { Mean egg weig } \\
\text { Ross } 308 \\
\text { Ross } 788 \\
\text { Cobb } 500 \\
\text { Hybro } \\
\text { Mean }\end{array}$ & $\begin{array}{l}65.9 \\
65.2 \\
65.2 \\
63.6 \\
65.0^{b}\end{array}$ & $\begin{array}{l}68.4 \\
68.5 \\
67.2 \\
65.9 \\
67.5^{\text {a }}\end{array}$ & $\begin{array}{l}67.1^{\mathrm{a}} \\
66.8^{\mathrm{a}} \\
66.2^{\mathrm{b}} \\
64.7^{\mathrm{c}}\end{array}$ & $\begin{array}{c}0.15 \\
15\end{array}$ & $\begin{array}{c}0.21 \\
15\end{array}$ \\
\hline $\begin{array}{c}\text { Egg mass }(\mathrm{kg} / \mathrm{b} \\
\text { Ross } 308 \\
\text { Ross } 788 \\
\text { Cobb } 500 \\
\text { Hybro } \\
\text { Mean }\end{array}$ & $\begin{array}{r}9.92 \\
10.08 \\
9.41 \\
8.78 \\
9.55\end{array}$ & $\begin{array}{l}9.97 \\
9.91 \\
8.95 \\
8.82 \\
9.41\end{array}$ & $\begin{array}{l}9.94^{\mathrm{a}} \\
9.99^{\mathrm{a}} \\
9.18^{\mathrm{b}} \\
8.80^{\mathrm{b}}\end{array}$ & $\begin{array}{c}0.139 \\
15\end{array}$ & $\begin{array}{c}0.197 \\
15\end{array}$ \\
\hline $\begin{array}{c}\text { Feed conversio } \\
\text { Ross } 308 \\
\text { Ross } 788 \\
\text { Cobb } 500 \\
\text { Hybro } \\
\text { Mean }\end{array}$ & $\begin{array}{l}5.48 \\
5.36 \\
5.85 \\
6.16 \\
5.71\end{array}$ & $\begin{array}{l}5.51 \\
5.51 \\
6.17 \\
6.23 \\
5.86\end{array}$ & $\begin{array}{l}5.50^{\mathrm{b}} \\
5.44^{\mathrm{b}} \\
6.01^{\mathrm{a}} \\
6.20^{\mathrm{a}}\end{array}$ & $\begin{array}{c}0.086 \\
15\end{array}$ & $\begin{array}{c}0.121 \\
15\end{array}$ \\
\hline $\begin{array}{c}\text { Feed conversio } \\
\text { Ross } 308 \\
\text { Ross } 788 \\
\text { Cobb } 500 \\
\text { Hybro } \\
\text { Mean }\end{array}$ & $\begin{array}{l}362 \\
350 \\
381 \\
392 \\
371^{\mathrm{b}}\end{array}$ & $\begin{array}{l}377 \\
377 \\
415 \\
411 \\
395^{\text {a }}\end{array}$ & $\begin{array}{l}369^{\mathrm{b}} \\
364^{\mathrm{b}} \\
398^{\mathrm{a}} \\
401^{\mathrm{a}}\end{array}$ & $\begin{array}{l}5.5 \\
15\end{array}$ & $\begin{array}{l}7.8 \\
15\end{array}$ \\
\hline
\end{tabular}

All birds were fed a $12.39 \mathrm{MJ} / \mathrm{kg}$ AME, $210 \mathrm{~g} \mathrm{CP} / \mathrm{kg}$ crumbled diet ad libitum until transfer to an $11.89 \mathrm{MJ} / \mathrm{kg}$ AME, $175 \mathrm{~g} \mathrm{CP} / \mathrm{kg}$ pelleted diet scattered on the litter floor and controlled feeding at two weeks. At six weeks, the diet specifications were changed to $11.5 \mathrm{MJ} / \mathrm{kg} \mathrm{AME}, 140 \mathrm{~g} \mathrm{CP} / \mathrm{kg}$, and finally, from $5 \%$ egg production until the end of the trial at 60 weeks, to an $11.5 \mathrm{MJ} / \mathrm{kg}$ AME, $145 \mathrm{~g} \mathrm{CP} / \mathrm{kg}$ pelleted layer diet, delivered in a feed trough (nominally, $125 \mathrm{~mm}$ linear trough space per hen) fitted with a male excluder. The trial included a comparison of two peak daily feed allocations during the laying phase: a progressive increase to reach $160 \mathrm{~g} /$ bird by 25 weeks or two further 10 -g weekly increases to reach 180 g/bird by 27 weeks. After 40 weeks of age, each group had its allocation reduced by $5 \mathrm{~g} / \mathrm{bird}$ for each $5 \%$ decline in rate of lay. There were no significant interactions of feeding treatment with either genotype or 
light, and so the nutritional effects are reported in a separate paper. Egg collections were recorded four times daily, egg weight measured three times weekly, and sample body weights at monthly intervals through to 60 weeks of age.

Table 2 Mean body weight at 20 weeks, $50 \%$ egg production, 59 weeks, body weight gain 20-59 weeks, and mortality for Ross 308, Ross 788, Cobb 500 and Hybro broiler breeders reared on $8 \mathrm{~h}$ and transferred to $12 \mathrm{~h}$ at 20 weeks followed by 1 -h weekly increments to $16 \mathrm{~h}$, or reared on $14 \mathrm{~h}$ and transferred abruptly to $16 \mathrm{~h}$ at 20 weeks

\begin{tabular}{|c|c|c|c|c|c|}
\hline & \multicolumn{2}{|c|}{ Rearing photoperiod } & \multicolumn{3}{|c|}{ SED and Res DF } \\
\hline & $8 \mathrm{~h}$ & $14 \mathrm{~h}$ & Mean & Light & Genotype \\
\hline $\begin{array}{l}\text { Body weight at } 20 \text { weeks }(\mathrm{kg}) \\
\text { Ross } 308 \\
\text { Ross } 788 \\
\text { Cobb } 500 \\
\text { Hybro } \\
\text { Mean }\end{array}$ & $\begin{array}{l}2.23 \\
2.16 \\
2.13 \\
2.03 \\
2.14^{\mathrm{a}}\end{array}$ & $\begin{array}{l}2.20 \\
2.08 \\
2.05 \\
1.98 \\
2.08^{b}\end{array}$ & $\begin{array}{l}2.22^{\mathrm{a}} \\
2.12^{\mathrm{b}} \\
2.09^{\mathrm{b}} \\
2.01^{\mathrm{c}}\end{array}$ & $\begin{array}{c}0.020 \\
23\end{array}$ & $\begin{array}{c}0.029 \\
23\end{array}$ \\
\hline $\begin{array}{l}\text { Body weight at } 50 \% \text { lay }(\mathrm{kg}) \\
\text { Ross } 308 \\
\text { Ross } 788 \\
\text { Cobb } 500 \\
\text { Hybro } \\
\text { Mean }\end{array}$ & $\begin{array}{l}3.09 \\
2.97 \\
3.20 \\
3.17 \\
3.11^{\mathrm{b}}\end{array}$ & $\begin{array}{l}3.72 \\
3.62 \\
3.86 \\
3.67 \\
3.72^{b}\end{array}$ & $\begin{array}{l}3.41^{\mathrm{b}} \\
3.30^{\mathrm{c}} \\
3.53^{\mathrm{a}} \\
3.42^{\mathrm{b}}\end{array}$ & $\begin{array}{c}0.037 \\
23\end{array}$ & $\begin{array}{c}0.052 \\
23\end{array}$ \\
\hline $\begin{array}{l}\text { Body weight at } 59 \text { weeks }(\mathrm{kg}) \\
\text { Ross } 308 \\
\text { Ross } 788 \\
\text { Cobb } 500 \\
\text { Hybro } \\
\text { Mean }\end{array}$ & $\begin{array}{l}4.31 \\
4.16 \\
4.51 \\
4.41 \\
4.35^{b}\end{array}$ & $\begin{array}{l}4.55 \\
4.23 \\
4.61 \\
4.56 \\
4.49^{\mathrm{a}}\end{array}$ & $\begin{array}{l}4.43^{\mathrm{b}} \\
4.20^{\mathrm{c}} \\
4.56^{\mathrm{a}} \\
4.48^{\mathrm{ab}}\end{array}$ & $\begin{array}{c}0.063 \\
15\end{array}$ & $\begin{array}{c}0.089 \\
15\end{array}$ \\
\hline $\begin{array}{l}\text { Body weight gain in lay }(\mathrm{kg}) \\
\text { Ross } 308 \\
\text { Ross } 788 \\
\text { Cobb } 500 \\
\text { Hybro } \\
\text { Mean }\end{array}$ & $\begin{array}{l}2.08 \\
2.00 \\
2.38 \\
2.38 \\
2.21^{\mathrm{b}}\end{array}$ & $\begin{array}{l}2.34 \\
2.15 \\
2.56 \\
2.57 \\
2.41^{\mathrm{a}}\end{array}$ & $\begin{array}{l}2.21^{\mathrm{b}} \\
2.07^{\mathrm{b}} \\
2.47^{\mathrm{a}} \\
2.48^{\mathrm{a}}\end{array}$ & $\begin{array}{c}0.061 \\
15\end{array}$ & $\begin{array}{c}0.086 \\
15\end{array}$ \\
\hline $\begin{array}{l}\text { Mortality 20-60 weeks (\%) } \\
\text { Ross } 308 \\
\text { Ross } 788 \\
\text { Cobb } 500 \\
\text { Hybro } \\
\text { Mean }\end{array}$ & $\begin{array}{r}11.0 \\
5.8 \\
11.3 \\
9.3 \\
9.3^{\mathrm{b}}\end{array}$ & $\begin{array}{l}13.0 \\
13.3 \\
11.3 \\
14.0 \\
12.9^{\text {a }}\end{array}$ & $\begin{array}{r}12.0 \\
9.5 \\
11.3 \\
11.6\end{array}$ & $\begin{array}{c}1.58 \\
14\end{array}$ & $\begin{array}{c}2.23 \\
14\end{array}$ \\
\hline
\end{tabular}

${ }^{\mathrm{a}, \mathrm{b}}$ Within rows (Light) or columns (Genotype), means with different superscripts are significantly different at $\mathrm{P}<0.05$

Data were subjected to a general linear model ANOVA from Genstat $6^{\text {th }}$ Edition (Lawes Agricultural Trust, 2002) using the lighting, genotype, and feeding treatments as variables and three-way interactions for all parameters except age at 50\% lay, which included only the lighting and genotype treatments as variables because sexual maturity was reached before the feeding treatments had been introduced. Mortality data were normalised by an arcsine transformation prior to their subjection to the ANOVA.

\section{Results}

The birds reared on 14-h photoperiods took, on average, $26 \mathrm{~d}$ longer to reach 50 eggs/100 bird.d (\%) egg production than those given a typical broiler breeder lighting regimen (8-h photoperiods to 20 weeks), ranging from a 21-d delay for Hybro to $29 \mathrm{~d}$ for Ross 788. As a consequence, the 14-h birds produced seven 
fewer eggs to 60 weeks than the 8-h birds, varying from four eggs less for Ross 308 and Hybro to 11 fewer eggs for the Cobb birds. Peak rate of lay for the 14-h birds was four weeks later (Figure 1) and 3\% lower (Figure 2) than for the 8-h birds, however, the $1.1 \%$ per week mean decline in rate of lay after peak production was significantly lower than the $1.5 \%$ of the 8 -h birds (Figure 2). This more gentle fall in egg

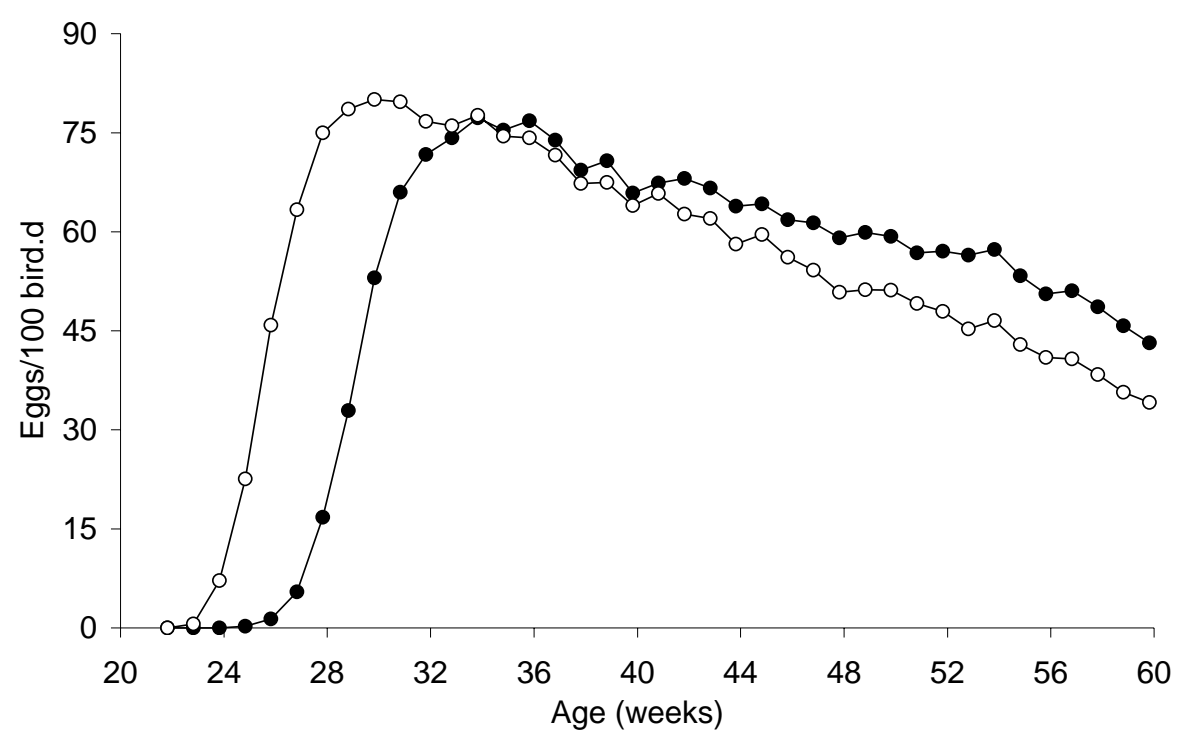

Figure 1 Mean weekly egg production for Ross 308, Ross 788, Cobb 500 and Hybro broiler breeders reared on $8 \mathrm{~h}$ and transferred to $12 \mathrm{~h}$ at 20 weeks followed by weekly increments of $1 \mathrm{~h}$ to $16 \mathrm{~h}(\mathrm{O})$, or reared on 14 $\mathrm{h}$ and transferred abruptly to $16 \mathrm{~h}$ at 20 weeks $(\bullet)$

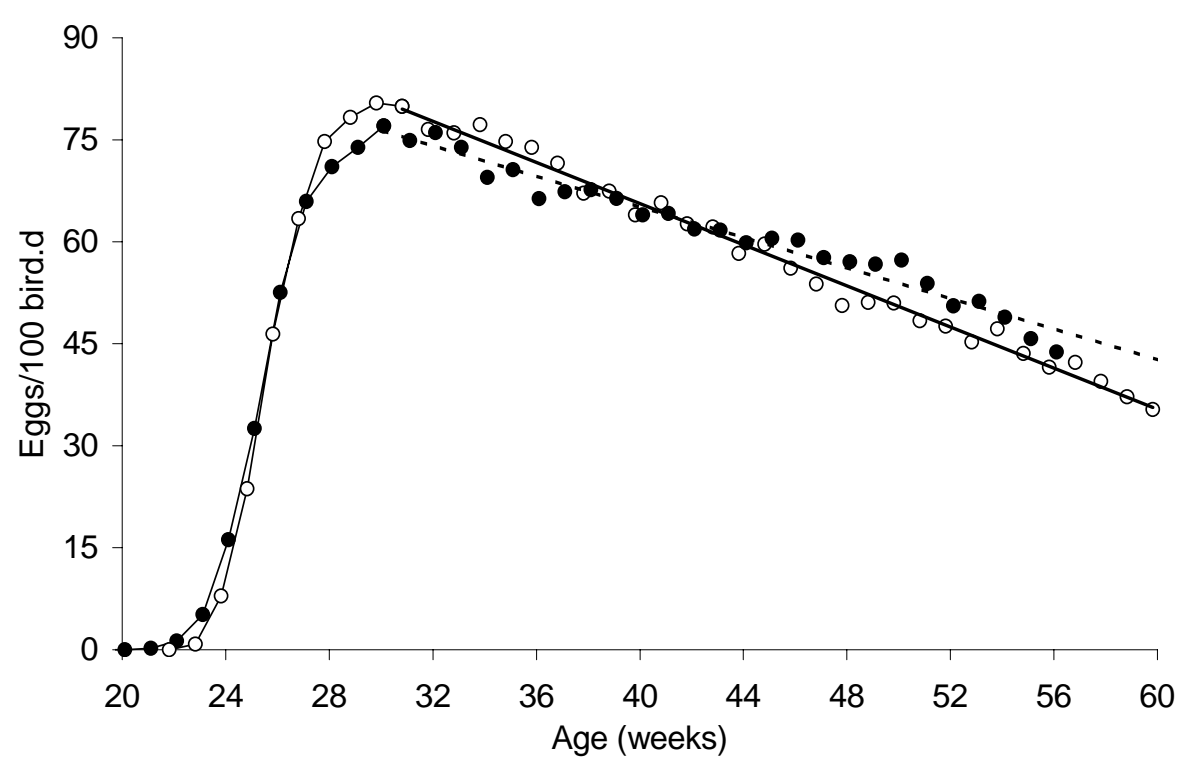

Figure 2 Mean weekly egg production for Ross 308, Ross 788, Cobb 500 and Hybro broiler breeders reared on 8-h and transferred to 12-h photoperiods at 20 weeks followed by weekly increments of $1 \mathrm{~h}$ to $16 \mathrm{~h}$ ( 0 and solid regression line), or reared on $14 \mathrm{~h}$ and transferred abruptly to $16 \mathrm{~h}$ at 20 weeks with data plotted $26 \mathrm{~d}$ earlier to adjust for the later mean age at $50 \%$ of these birds ( $\bullet$ and dotted regression line) 


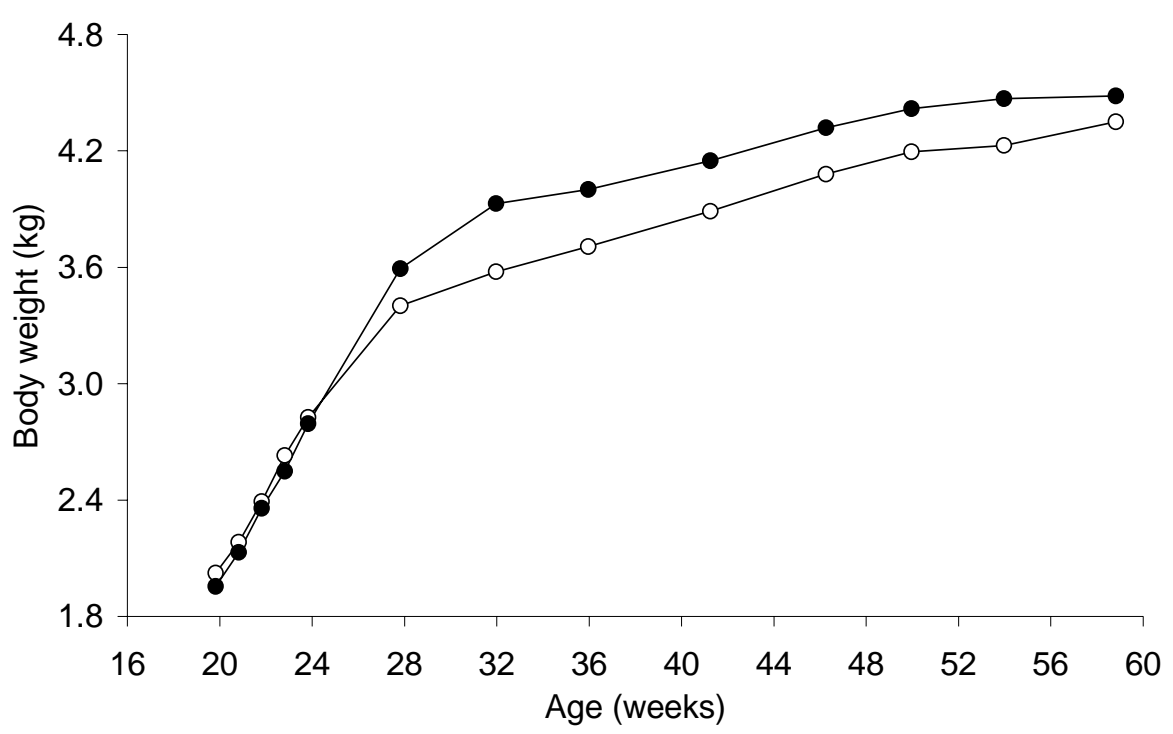

Figure 3 Mean body weight for Ross 308, Ross 788, Cobb 500 and Hybro broiler breeders reared on 8 h and transferred to $12 \mathrm{~h}$ at 20 weeks followed by weekly increments of $1 \mathrm{~h}$ to $16 \mathrm{~h}(\mathrm{O})$, or reared on $14 \mathrm{~h}$ and transferred abruptly to $16 \mathrm{~h}$ at 20 weeks $(\bullet)$

production by the 14-h birds was seen in all genotypes and resulted in their weekly rate of lay being significantly higher than that of the 8-h birds from 42 weeks onwards (Figure 1).

The later sexual maturity of the 14-h birds meant that these birds had a 600 -g heavier body weight at $50 \%$ egg production than the birds reared on $8 \mathrm{~h}$ (Table 2), which led to a 2.5 -g increase in mean egg weight, ranging from $2.0 \mathrm{~g}$ for Cobb to $3.3 \mathrm{~g}$ for Ross $788 \mathrm{birds}$ (Table 1). As a consequence, there were no significant differences in egg mass output between the two lighting groups for any of the genotypes. The reduction in egg numbers but increased egg weight, together with a 700-g higher cumulative feed intake to 60 weeks (better rates of lay after 42 weeks necessitated higher daily feed allocations), resulted in the 14-h birds using $24 \mathrm{~g}$ more feed to produce an egg (Table 2). There was no interaction between lighting and breed, but Cobb and Hybro required significantly more feed to produce an egg than either of the Ross genotypes (Table 2). The similar egg mass outputs of the two lighting treatments, however, resulted in no significant difference in the efficiencies with which the two groups converted feed into egg mass $(\mathrm{P}=0.114)$, despite each breed using numerically more feed to produce a given weight of egg when reared on $14 \mathrm{~h}$. Cobb and Hybro birds, again, converted feed less efficiently than either of the Ross genotypes (Table 2).

Although the 14-h birds had a $0.06-\mathrm{kg}$ lighter body weight at 20 weeks, their significantly larger body weight gain between 24 and 28 weeks (Figure 3), when the 8-h birds were in-lay but they were still sexually immature, resulted in them being significantly heavier at 28 weeks and at all other ages for the remainder of the trial.

The incidence of mortality during the laying cycle was significantly higher for 14-h than for 8-h birds, but was similar for all genotypes (Table 2).

\section{Discussion}

These data confirm the earlier findings (Payne, 1975; Lewis et al., 2003; Gous \& Cherry, 2004; Lewis $\&$ Gous, 2006) that rearing broiler breeders on long days causes a delay in their sexual development, compared with birds reared on short days, and a consequential reduction in egg numbers but increase in egg weight. The similar relative responses to the 8-h and 14-h rearing photoperiods by all four genotypes indicates that the need to provide a period of short days to expedite the dissipation of juvenile photorefractoriness most probably applies to all normal size broiler breeders, and the agreement of these findings with those of Payne (1975) shows that the consequences of not providing a period of short days has changed little in the past 30 years. In addition to the slower dissipation of photorefractoriness, sexual maturation was also later for the 14-h birds because a transfer from 14 to $16 \mathrm{~h}$ is less stimulatory than one 
from 8 to $12 \mathrm{~h}$ (Lewis et al., 2007). Lewis et al. (2005b) found that rearing broiler breeders on an increasing daylength regimen, similar to that typically experienced by spring-hatched birds reared in non-lightproof housing in South Africa, resulted in neither precocity nor the production of small eggs, but that rearing on 14-h photoperiods to avoid the hypothetical problem of precocity does reduce egg numbers; precocity can be satisfactorily controlled by the feeding programme. The longer time taken by the Hybro birds to reach $50 \%$ egg production, compared with the other three genotypes, could partly be explained by their lower body weight at 20 week; Lewis et al. (2007) concluded that sexual maturity was delayed in broiler breeders by $2 \mathrm{~d}$ for each $100-\mathrm{g}$ reduction in body weight at 20 weeks.

A meta-analysis of eggs produced to 60 weeks on age at $50 \%$ rate of lay, using 71 sets of data from this and earlier experiments at the University of KwaZulu-Natal, showed that egg numbers decreased by 3.8 for each 10-d delay in maturity. This suggests that the production of seven fewer eggs by the birds reared on 14-h photoperiods in this experiment were principally a consequence of their later maturation ( $26 \mathrm{~d} \times 0.38$ eggs $=9.9$ eggs). A meta-analysis of mean egg weights from the same 71 data sets, together with mean body weights at 20 weeks, revealed that egg weight increased by $0.97 \mathrm{~g}$ for each 10 -d later maturity, and so the $2.5 \mathrm{-g}$ heavier mean egg weight of the birds reared on $14 \mathrm{~h}$ is in complete agreement with this prediction $(26 \mathrm{~d} \times 0.97 \mathrm{~g}=2.5 \mathrm{~g})$. The egg weight $(E W)$ prediction was described by the equation:

$$
E W=43.46+0.097 A S M+1.97 B W
$$

where $A S M=$ age at $50 \%$ egg production (d) and $B W=$ mean body weight at 20 weeks $(\mathrm{kg})$. This equation predicts mean egg weights of $65.1 \mathrm{~g}$ for the 8 -h and $67.5 \mathrm{~g}$ for the 14 -h birds in this experiment, which agrees remarkably well with the observed figures of 65.0 and $67.5 \mathrm{~g}$ (Table 1), and shows that the effects of the different lighting regimens on egg numbers and egg weight can be attributed exclusively to their effects on sexual maturation and to the body weight of the birds at photostimulation.

The conclusion from these two experiments is that, irrespective of breed, season of hatch, or lighttightness of the facilities, broiler breeders should be given a period of short days during the rearing period to expedite the acquisition of photosensitivity, and that the economic consequences of not doing so are such that serious consideration should be given to lightproofing facilities rather than to the use of long days.

\section{References}

Gous, R.M. \& Cherry, P., 2004. Effects of body weight at, and lighting regimen and growth curve to, 20 weeks on laying performance in broiler breeders. Br. Poult. Sci. 45, 445-452.

Lawes Agricultural Trust, 2002. Genstat 6th Edition, Version 6.1.0.205. VSN International, Oxford, UK.

Lewis, P.D. \& Gous, R.M., 2006. Various photoperiods and Biomittent ${ }^{\mathrm{TM}}$ lighting during rearing for broiler breeders subsequently transferred to open-sided housing at 20 weeks. Br. Poult. Sci., 47, 24-29.

Lewis, P.D., Backhouse, D. \& Gous, R.M., 2004. Constant photoperiods and sexual maturity in broiler breeder pullets. Br. Poult. Sci. 45, 557-560.

Lewis, P.D., Backhouse, D. \& Gous, R.M., 2005a. Effects of constant photoperiods on the laying performance of broiler breeders allowed conventional or accelerated growth. J. Agric. Sci. 143, 97-108.

Lewis, P.D., Ciacciariello, M. \& Gous, R.M., 2003. Photorefractoriness in broiler breeders: Sexual maturity and egg production evidence. Br. Poult. Sci. 44, 634-642.

Lewis, P.D., Gous, R.M. \& Morris, T.R., 2007. A model to predict sexual maturity in broiler breeders given a single increment in photoperiod. Br. Poult. Sci. (in press).

Lewis, P.D., Ciacciariello, M., Nonis, M. \& Gous, R.M., 2005b. Simulated natural lighting and constant 14-hour photoperiods for broiler breeders during the rearing period, and interactions of lighting with body weight. S. Afr. J. Anim. Sci. 35, 1-12.

Payne, C.G., 1975. Day-length during rearing and the subsequent egg production of meat-strain pullets. Br. Poult. Sci., 16, 559-563. 